\title{
OPTIMALISASI FUNGSI INTELIJEN KEPOLISIAN DALAM PENYELIDIKAN TINDAK PINDANA NARKOTIKA YANG DILAKUKAN ANGGOTA KEPOLISIAN ( Studi Sat Intelkam Polres Solok)
}

Herius Harefa ${ }^{1}$, Fitriati $^{2}$, Ferdi $^{3}$ Program Studi Pascasarjana Ilmu Hukum Universitas Ekasakti Padang

\begin{abstract}
One of the tasks of intelligence is to investigate members of the Police who commit criminal acts of narcotics abuse. Based on this, the problems described are the first, how the Police Intelligence Function and constraints in the Investigation of Narcotics Crimes committed by Solok Police Force Members and the Optimization of the Intelligence Functions. The specifications of this study are analytical descriptive. While the method of approach used is juridical empiris.Teknik data collection is a field study through interviews for primary data and literature study to obtain secondary data. The data obtained are then analyzed qualitatively. The first conclusion of the Police Intelligence Function in the investigation and supervision of members of the Police who committed the narcotic crime is to search, dig, and collect data as completely as possible from various sources. Both obstacles encountered in the execution of these functions are law enforcement factors where the Police must crack down on its members who commit a crime not to protect its members who are involved in narcotic criminal acts. Efforts Optimizing the intelligence function in investigating drug abuse by members of Polri is Conducting Education and training for members of Intelligence, Coordinating and cooperation with related institutions and institutions. Repressive efforts as law enforcement efforts in the form of repression, eradication, crackdown after the crime occurred.
\end{abstract}

Kata Kunci : Optimalisasi, Intelejen, Penyelidikan, Anggota Polri

\section{PENDAHULUAN}

Tugas pokok dan fungsi Intelijen dan

Keamanan (Intelkam) dilingkungan Polri

diatur berdasarkan Peraturan Kepala

Kepolisian Negara Republik Indonesia

Nomor 22 Tahun 2010 tentang Susunan

Organisasi dan Tata Kerja pada Tingkat

Kepolisian Daerah dan Peraturan Kepala

Kepolisian Negara Republik Indonesia
Nomor 23 Tahun 2010 tentang Susunan Organisasi dan Tata kerja pada Tingkat Kepolisian Resor (Polres) dan Kepolisian Sektor (Polsek)

Selain itu, dalam menciptakan situasi yang kondusif ditengah masyarakat, Intelijen harus membangun hubungan yang baik dengan masyarakat. Sehingga Informasi yang ada dan sedang berkembang ditengah masyarakat mudah untuk didapatkan, seperti 
kasus yang berkaitan dengan narkotika. Suatu tindak pidana itu dapat terjadi pada siapapun dan dapat dilakukan oleh siapapun. Tindak pidana merupakan suatu tindakan atau perbuatan yang dilakukan oleh manusia yang mana perbuatan tersebut dilarang oleh undang-undang hukum pidana.

Penyalahgunaan dan peredaran gelap narkotika bukanlah hal yang baru di Indonesia. Tindak pidana Narkotika merupakan bentuk pelanggaran hukum dan pelanggaran norma sosial yang telah ada sejak lama. Masalah Narkotika ini merupakan ancaman yang begitu hebat melanda indonesia, dalam media massa hampir setiap hari terdapat berita penyalahgunaan Narkotika. Narkotika adalah zat yang dapat menimbulkan pengaruh tertentu bagi mereka yang menggunakan dengan cara memasukan obat tersebut dalam tubuhnya, pengaruh tersebut merupakan pembiasan, hilangnya rasa sakit rangsanggan, semangat dan halusinasi.(Juliasa Lisa, 2003:1) Narkotika termasuk bahan adiktif karena menimbul-kan ketergantungan dan tergolong zat psikoaktif, artinya berpengaruh kepada kerja otak dan mengubah prilaku pemakainya.

Situasi keamanan masyarakat dan tindak kriminalitas memiliki kecendrungan meningkat dari tahun ke tahun seirama dengan perkembangan berbagai aspek kehidupan masyarakat, sementara itu situasi keamanan dan ketertiban yang kondusif di wilayah adalah mutlak, untuk mewujudkan guna mendukung terselenggaranya pembangunan daerah sampai ke tingkat nasional termasuk berjalannya roda pemerintahan dan perekonomian bangsa. Fungsi Intelkam sebagai pelaksana fungsi intelijen keamanan yang meliputi penyelidikan, pengamanan dan penggalangan guna terpeliharanya stabilitas keamanan dan ketertiban masyarakat yang kondusif, harus dapat mengantisipasi berbagai perkembangan situasi sehingga apabila muncul ancaman faktual dapat ditangani secara profesional dan proporsional sesuai dengan prosedur yang ditetapkan dalam peraturan perundang-undangan. Fungsi Intelkam Polri sangat berperan dalam memberikan masukan kepada pimpinan tentang perkembangan keamanan dan ketertiban dalam masyarakat. Diperlukan analisa intelijen yang tajam dan akurat sehingga segala kemungkinan tentang perkembangan kamtibmas dapat diantisipasi oleh kepolisian. Maka dituntut peran dan fungsi Intelkam dalam menjalankan tugasnya dalam menghadapi perkembangan paradigma kamtibmas yang terjadi di wilayah tugasnya masing-masing.

Perkembangan suatu organisasi salah satunya adalah mampu membaca perubahan yang ada dilingkungannya, baik internal maupun eksteral sebagai mana dalam suatu pepatah lama menyebutkan "kita biasa memenangkan peperangan kalau mempunyai/menguasai informasi yang lengkap, akurat, tepat dan valid adalah sangat 
menentukan keberhasilan suatu organisasi. (Driyanto, 2007:6)

Penyalahgunaan dan peredaran gelap Narkotika semakin meningkat dari tahun ke tahun. Telah banyak yang menjadi korban tanpa memandang umur dan status sosial. Ironisnya, penyalahgunaan dan peredaran Narkotika sudah merambah sampai kesemua kalangan menjadi korban. Tidak hanya masyarakat atau remaja biasa saja yang telah menjadi korban penyalahgunaan narkotika, bahkan aparat kepolisian yang notabene merupan penegak hukum yang seharunya memberantas peredaran gelap Narkotika justru ikut bergabung. Institusi polri merupakan garda terdepan dalam hal pelayanan publik khususnya memberikan keamanan dan kenyamanan serta mencegah peredaran Narkotika. Terlibatnya anggota polri dalam peredaran Narkotika merupakan hal yang menciderai citra kepolisian dimata masyarakat.

Pasal 1 ayat (20) Undang-undang Nomor 35 Tahun 2009 tentang Narkotika menyatakan bahwa kejahatan terorganisasi adalah kejahatan yang dilakukan oleh suatu kelompok yang terstruktur yang terdiri atas 3 (tiga) orang atau lebih yang telah ada untuk suatu waktu tertentu dan bertindak bersama dengan tujuan melakukan suatu tindaka pidana narkotika. Kemudian dalam Pasal 81 Undang-undang Nomor 35 Tahun 2009 tentang Narkotika menyatakan bahwa penyidik Kepolisian Negara Republik
Indonesia dan Penyidik Badan Narkotika Nasional (BNN) berwenang melakukan penyidikan terhadap penyalahgunaan dan peredaran gelap Narkotika dan prekursor Narkotika berdasarkan undang-undang.

Kepolisian Resor Solok (Polres Solok) berada dilintas sumatera bertempat di jorong lubuk selasih Nagari Batang Barus Kecamatan Gunung Talang Kabupaten Solok Provinsi Sumatera Barat. Kepolisian Resor (Polres) Solok di pimpin oleh Kepala Kepolisian Resor (Kapolres) dan dibantu oleh Wakil Kepala (Waka) dalam melaksanakan Tugas Pokok Kepolisian sebagaimana dimaksud dalam Pasal 13 Undang-undang Republik Indonesia Nomor 2 Tahun 2002 tentang Kepolisian. Kemudian di Polres Solok adanya beberapa orang anggota atau personil yang melakukan penyalahgunaan narkotika. Dengan dibuktikan banyaknya laporan informasi yang dilaporkan oleh Satuan Intelijen dan keamanan (Sat Intelkam) Polres Solok. Penyelidikan yang dilakukan oleh satuan Intelijen dan Keamanan (Sat Intelkam) Polres Solok sering menemui berbagai kendala hal ini terutama karena pelaku juga anggota kepolisian sendiri. Adanya rasa setia kawan sesama anggota menjadi salah satu kendala dalam proses penyelidikan tersebut.

Pada awal Tahun 2015 yang lalu, Satuan Intelijen dan Keamanan (Sat Intelkam) Polres Solok berhasil mengungkap peredaran gelap Narkotika yang dilakukan oleh salah seorang oknum anggota Kepolisian Resor 
Solok. Keberhasilan pengungkapan peredaran gelap dan penyalahgunaan narkotika tersebut berawal dari adanya laporan informasi masyarakat yang disampaikan kepada satuan Intelijen dan Keamanan (Sat Intelkam) Polres Solok. Hal itu bukti kepercayaan dan dukungan masyarakat terhadap satuan Intelijen dan Keamanan (Sat Intelkam) Polres Solok khususnya dan Polri secara umumnya sebagai pelindung, pengayom dan pelayan masyarakat.

\section{METODE PENELITIAN}

Spesifikasi penelitian adalah deskriptif analisis, dengan metode pendekatan yuridis sosiologis. Jenis data yang digunakan adalah data sekunder dan data primer. Data sekunder diperoleh dari studi dokumen dan studi kepustakaan sedangkan data primer diperoleh dari studi lapangan di Polres Solok. Teknik pengumpulan data pada data primer dilakukan dengan wawancara secara semi terstruktur. Data yang diperoleh kemudian dianalisa secara kualitatif .

\section{HASIL PENELITIAN DAN ANALISIS}

Fungsi Intelijen Kepolisian dalam

Penyelidikan Tindak Pidana Narkotika yang dilakukan Anggota Kepolisian Resor

Solok.

Intelijen berkaitan dengan proses penginderaan awal atau lebih dikenal dengan early warning system (sistem peringatan dini). Kegiatan intelijen merupakan bagian integral sistem peringatan dini yang memungkinkan pembuat kebijakan memiliki fore knowledge ( kewaspadaan dini).

Dalam rangka pelaksanaan tugas-tugas intelijen di lingkungan Polri, kegiatan operasional Intelkam diklasifikasikan dalam tiga bentuk yang berlaku juga secara universal yaitu penyelidikan, pengamanan, dan penggalangan. Kegiatan operasional Intelkam dilakukan dengan tujuan untuk memperoleh informasi, mengamankan obyek/aktivitas tertentu, serta menciptakan kondisi yang kondusif bagi pelaksanaan tugas Polri lainnya. Kegiatan operasional Intelkam dapat dilaksanakan secara terbuka maupun secara tertutup.

Menurut Kunarto penyelidikan merupakan upaya mencari dan mengumpulkan bahan informasi; pengamanan merupakan upaya mengamankan organisasi agar tidak menjadi sasasaran lawan; penggalangan merupakan upaya untuk menciptakan kondisi dan situasi yang menguntungkan organisasi. Oleh karena itu, spektrum kegiatan Intelkam dalam pelaksanaan tugas Polri adalah mendahului, menyertai dan mengakhiri setiap kegiatan operasional kepolisian yang dilakukan oleh Polri. Penyelidikan dalam Intelkam adalah kegiatan yang merupakan bagian integral fungsi intelijen untuk mencari, mengumpulkan, mengolah data (bahan keterangan) dan menyajikan informasi sebagai usaha penginderaan dan peringatan 
dini bagi pimpinan Polri, baik dalam bidang pembinaan maupun operasional kepolisian sehingga hasilnya berguna/diperlukan dalam pelaksanaan tugas-tugas Polri. Penyelidikan dilakukan untuk mencari, menggali, dan menggumpulkan data selengkap mungkin dari berbagai sumber, baik itu sumber terbuka maupun tertutup melalui kegiatan yang juga terbuka maupun tertutup, kemudian data tersebut diolah menjadi produk intelijen yaitu informasi yang siap digunakan sebagai dasar pengambilan keputusan atau tindakan.

Begitu juga dalam pengawasan terhadap prilaku anggota Polri yang menyalahgunakan narkotika yang dilakukan oleh Sat intelkam. Seperti diketahui bahwa Polisi sebagai aparat penegak hukum dituntut untuk dapat bertindak secara profesional sesuai dengan tugas Polisi. Pembinaan merupakan salah satu upaya antisipasi cegah dini yang dilakukan oleh Polri melalui kegiatan-kegiatan dengan tujuan menghilangkan alasan peluang dan pendorong Anggota Polri melakukan Tindak Pidana Narkotika. Tujuan dilaksanakannya kegiatan ini untuk menghilangkan faktor peluang dan pendorong terkontaminasinya seseorang menjadi pengguna, serta menciptakan daya tangkal dan memotivasi membangkitkan kesadaran anggota Polri agar tidak melakukan Tindak Pidana Narkotika, Contoh langkah yang di ambil ialah dengan diadakannya tes urine.
Pengamanan dalam konteks Intelkam adalah segala usaha, pekerjaan, kegiatan intelijen yang ditujukan untuk mendukung penyelenggaraan tugas pokok Polri yang dilaksanakan dengan menerapkan prosedur, metode, tehnik dan taktik berupa langkah-langkah pencegahan dan penindakan baik langsung, terbuka ataupun tertutup yang terhadap segala bentuk ancaman yang mungkin terjadi berupa penyimpangan norma-norma untuk menjamin keamanan dan ketertiban dalam kehidupan, serta yang dapat diperkirakan akan menghambat kelancaran pelaksanaan pembangunan bangsa yang bersumber dari supra struktur, tehnostruktur, warga masyarakat dan lingkungan. Pengamanan adalah upaya, langkah, dan tindakan yang dilakukan dengan tujuan untuk mangamankan suatu lingkungan beserta dengan segala isinya agar tercipta suasana aman dan tertib serta mensterilkan dari segala bentuk ancaman, gangguan, hambatan dan tantangan.

Tindak pidana narkotika yang dilakukan oleh polisi. Mengenai penegakan hukum pidana sebenarnya tidak hanya bagaimana cara membuat hukum itu sendiri, melainkan juga mengenai apa yang harus dilakukan oleh aparatur penegak hukum dalam mengantisipasi dan mengatasi masalah-masalah dalam penegakan hukum. mengenai tindak pidana narkotika yang dilakukan oleh anggota polisi tersebut maka dapat dilakukan upaya respresif. Karena 
perbuatan yang dilakukan oleh anggota polisi tersebut bertentangan dengan hukum. Penegakan hukum dapat digunakan dalam rangka penyerasian nilai- nilai atau normanorma yang ada pada masyarakat.

Intelijen dan keamanan adalah fungsi intelijen yang diterapkan dalam pelaksanaan tugas kepolisian. Menurut Karwita dan Saronto, tugas pokok Intelkam dapat dirumuskan dalam empat kegiatan sebagai berikut :

a. Melakukan deteksi terhadap segala perubahan kehidupan sosial dalam masyarakat serta perkembangannya di bidang ideologi, politik, sosial budaya, pertahanan dan keamanan untuk dapat menandai kemungkinan adanya aspekaspek kriminogen, selanjutnya mangadakan identifikasi hakikat ancaman terhadap Kamtibmas;

b. Menyelenggarakan fungsi intelijen yang diarahkan ke dalam tubuh Polri sendiri dengan sasaran pengamanan material, personil dan bahan keterangan serta kegiatan badan/kesatuan, teradap kemungkikan adanya tantangan yang bersumber dari luar maupun dari dalam tubuh Polri agar Polri tidak terhalang atau terganggu dalam melaksanakan tugas pokoknya;

c. Melakukan penggalangan dalam rangka menciptakan kondisi tertentu dalam masyarakat yang menguntungkan bagi pelaksanaan tugas poko Polri; d. Melakukan pengamanan terhadap sasasaran-sasaran tertentu dalam rangka mencegah kemungkinan adanya pihakpihak tertentu memperoleh peluang dan dapat memenfaatkan kelemahankelemahan dalam bidang Ipleksosbud Hankam, sebagi sarana ekploitasi untuk menciptakan suasana pertentangan patif menjadi aktif, sehingga menimbulkan ancaman atau gangguan di bidang Kamtibmas.

Intelejen juga memberikan arahan, bimbingan, serta Nasehat kepada seluruh anggota kepolisian Resor Solok untuk tidak menyalahgunakan narkotika. sebab jika terbukti menyalahgunakan Narkotika, anggota tersebut akan diproses secara pidana umum yang tuntutan hukumannya lebih berat. Anggota yang terlibat tindak pidana narkotika dapat diketahui dengan penyelidikan yang dilakukan intelejen.

Upaya penanggulangan penyalahgunaan narkotika ini tidak terlepas dari tindakan-tindakan Polri yang bersifat interdisipliner yang diawali dengan upaya preemtif (pembinaan) dan preventif (pencegahan) sebelum tindak pidana tersebut terjadi. Menurut M.Kemal Darmawan dalam bukunya yang berjudul "Strategi Kepolisian Dalam Pencegahan Kejahatan", definisi dari preemtif dan preventif adalah.

1. Pre-emtif adalah kebijakan yang melihat akar masalah utama penyebab terjadinya kejahatan melalui pendekatan sosial, 
pendekatan situasional dan pendekatan kemasyarakatan untuk menghilangkan unsur Potensi Gangguan (Faktor Korelatif Kriminogen).

2. Preventif sebagai upaya pencegahan atas timbulnya Ambang Gangguan (police hazard), agar tidak berlanjut menjadi gangguan nyata/ Ancaman Faktual (crime).

Sejalan dengan tugas pokok tersebut di atas, Sat Intelkam Polres Solok melakukan deteksi dini agar mengetahui segala perubahan kehidupan sosial yang terjadi pada diri seorang anggota Polri serta perkembangan selanjutnya, mengidentifikasikan hakekat ancaman yang tengah dan akan dihadapi, kemudian memberikan peringatan dini sebagai bahan dasar serta penentuan arah bagi kebijaksanaan dan pengambilan keputusan/tindakan oleh pimpinan Polri.

\section{Kendala Yang Dihadapi Intelijen Kepolisian Dalam Penyelidikan Tindak} Pidana Narkotika Yang Dilakukan Anggota Kepolisian Resor Solok

Pada pelaksanaan fungsi intelejen untuk menyelidiki anggota Polri yang terlibat tindak pidana narkotika juga menemui kendala dalam berbagai hal. Adapun Kendala

- Kendala tersebut adalah:

1. Aparat Penegak Hukum

Penegak hukum adalah mereka yang secara langsung dan secara tidak langsung berkencimpung didalam penegakan hukum. penegak hukum akan dibatasi pada kalangan yang bekecimpung dalam bidang penegakan hukum yang tidak mencakup law enforcement, akan tetapi juga peace maintenance.

2. Sarana atau Fasilitas

Berdasarkan hasil penelitian bahwa penegakan hukum terhadap tindak pidana narkotika yang dilakukan polisi masih kurang maksimal atau dapat dikatakan kurang dapat berjalan disebabkan karena kurangnya sarana dan prasarana yang memadai dan keterbatasan anggaran yang cukup, sehingga hal tersebut sangat mengganggu kegiatan sehari-hari.

3. Pengaruh Lingkungan atau masyarakat Menurut penulis terkait anggota Polri yang dalam hal ini sebagai objek dalam penegakan hukum. Latar belakang dan karakteristik pribadi yang dimiliki anggota Polisi membuatnya lebih cerdik dan pintar dalam menghindar dari pengejaran petugas.

4. Faktor Media

Anggota Polri yang menyalahgunakan Narkotika dengan mudah mendapatkan informasi tentang kegiatan anggota Satuan Intelijen dan keamanan yang sedang melakukan penyelidikan Tindak Pidana Narkotika, karena besar kemungkinan mengetahui setiap tindakan dilapangan, Khususnya dijajaran kepolisian, informasi anggota yang melakukan penyalahgunaan 
Narkoba rumit dan sukar untuk didapatkan.

\section{Optimalisasi Fungsi Intelejen dalam}

Penyelidikan Tindak Pidana Narkotika yang dilakukan Anggota Kepolisian Resor Solok.

Usaha Mengoptimalisasi fungsi intelejen dalam menyelidiki penyalah-gunaan narkotika oleh anggota Polri maka dilakukan upaya-upaya dengan langkah-langkah sebagai berikut:

1. Mengadakan Pendidikan dan pelatihan bagi anggota Intelejen

2. Melakukan koordinasi dan kerjasama

Upaya Represif merupakan upaya terakhir dalam memberantas penyalahgunaan narkotika yaitu dengan cara melakukan penindakan terhadap orang yang diduga menggunakan, menyimpan, menjual narkotika. Langkah represif inilah yang dilakukan Polisi dengan bekerjasama dengan Satuan Reskrim pada Polres Solok dan Propam untuk memberikan tindakan tegas dan konsisten sehingga dapat membuat jera para pelaku penyalahgunaan dan peredaran gelap narkotika.

Upaya represif adalah sebagai bentuk dari penegakan hukum terhadap tindak pidana narkotika yang dilakukan polisi. Penegakan hukum dilakukan secara represif oleh aparat penegak hukum, berupa penjatuhan sanksi oleh pelaku kejahatan, dalam hal ini dilakukan oleh kepolisian, kejaksaan, pengadilan, dan lembaga pemasyarakatan. Represif sebagai upaya penegakan hukum terhadap gangguan nyata atau ancaman faktual berupa penindakan, pemberantasan, penumpasan sasudah kejahatan terjadi atau pelanggaran hukumyang bertujuan untuk memberikan contoh social learning dan menimbulkan efek deterence agar dapat mengantisipasi para pelaku mengulangi perbuatannya.

Penegak hukum yang diharapkan masyarakat tentunya mampu melakukan perlindungan dan penegakan hukum secara tegas dan proporsional. Menurut AKP Sosmedya, SH.MH, menjelaskan bahwa penegakan hukum pidana khususnya pada tindak pidana narkotika maka upaya penal yang digunakan dengan menitik beratkan pada sifat represif yaitu dengan cara pemberantasan dan penumpasan.karna dalam tindak pidana narkotika ini kita perlu melakukan upaya pemberantasan dan penumpasan sesuai dengan hukum yang berlaku. Tidak menutup kemungkinan apabila ada anggota Polri yang terlibat dalam tindak pidana narkotika akan tetap diproses sesuai hukum.

\section{PENUTUP}

Fungsi Intelejen Polri dalam penyelidikan terhadap anggota Polri yang melakukan tindak pidana narkotika adalah dengan mencari, menggali, dan 
mengumpulkan data selengkap mungkin dari berbagai sumber, baik itu sumber terbuka maupun tertutup melalui kegiatan yang juga terbuka maupun tertutup, kemudian data tersebut diolah menjadi produk intelijen yaitu informasi yang siap digunakan sebagai dasar pengambilan keputusan atau tindakan. Begitu juga dalam pengawasan terhadap prilaku anggota Polri yang menyalahgunakan narkotika. Pada pelaksanaan fungsi intelejen untuk menyelidiki anggota Polri yang terlibat tindak pidana narkotika juga menemui kendala dalam berbagai hal. Adapun Kendala-Kendala tersebut adalah faktor penegak hukum yang mengakibatkan terhambatnya penegakan hukum terhadap tindak pidana narkotika yang dilakukan Polisi. Polri harus menindak anggotanya yang melakukan tindak pidana jangan sampai melindungi anggotanya yang terlibat tindak pidana narkotika. Selama ini masih adanya diantara pimpinan satuan selaku Aparat penegak hukum belum maksimal dalam memberikan sanksi kepada anggota Polisi yang melakukan pelanggaran. Usaha Mengoptimalisasi fungsi intelejen dalam menyelidiki penyalahgunaan narkotika oleh anggota Polri maka dilakukan upaya-upaya dengan langkah-langkah sebagai berikut: Mengadakan Pendidikan dan pelatihan bagi anggota Intelejen, Melakukan koordinasi dan kerjasama dengan instansi dan lembaga terkait, lembaga swadaya masyarakat, perkumpulan, Ormas dan lain-lain. Represif sebagai upaya penegakan hukum terhadap gangguan nyata atau ancaman faktual berupa penindakan, pemberantasan, penumpasan sesudah kejahatan terjadi atau pelanggaran hukumyang bertujuan untuk memberikan contoh social learning dan menimbulkan efek deterence agar dapat mengantisipasi para pelaku mengulangi perbuatannya.

\section{DAFTAR PUSTAKA}

Driyanto Ed Al, Modul B 2314 FT. Intel, Sekolah Calon Perwira Polri Januari 2007.

Juliana lisa, Nengah Sutrisna, Narkoba, psikotropika dan gangguan jiwa, Nuha Medika, Yogyakarta, 2003

Kunarto, Intelijen: Pengertian dan pemahamannya, Cipta Manunggal, Jakarta, 1999

Kunarto dan Karwita, Intelijen: Teori, Aplikas, dan Moderenisasi, PT. Ekalaya Saputra, Jakarta, 2000

Kemal Dermawan. Strategi Pencegahan Kejahatan, Citra Aditya Bakti, Bandung , 1994

Pusdik Intelkam, Teori dasar Intelijen ( bahan ajar), Pusdik Intelkam , Bandung, 2008 